\title{
PROFIL KREATIVITAS SISWA DALAM MENYELESAIKAN SOAL DITINJAU DARI KECEMASAN MATEMATIKA
}

\author{
Eko Rahmad Bahrudin \\ Program Studi Pendidikan Matematika, Fakultas Matematika dan Ilmu Pengetahuan Alam, Universitas Negeri \\ Surabaya. \\ ekobahrudin16030174075@mhs.unesa.ac.id
}

\section{Tatag Yuli Eko Siswono}

Program Studi Pendidikan Matematika, Fakultas Matematika dan Ilmu Pengetahuan Alam, Universitas Negeri Surabaya.

\begin{abstract}
tatagsiswono@unesa.ac.id
Abstrak

Kreativitas merupakan produk dari berpikir kreatif. Berpikir kreatif adalah kegiatan mental yang mengaitkan ide satu dengan ide lainnya untuk menemukan berbagai solusi atau gagasan baru dalam menyelesaikan soal. Salah satu faktor yang dapat memengaruhi berpikir kreatif siswa yaitu kecemasan matematika. Kecemasan matematika adalah suatu keadaan yang dialami siswa berupa perasaan takut, gelisah, dan cemas ketika dihadapkan pada permasalahan matematika. Terdapat korelasi negatif yang tinggi antara kemampuan berpikir kreatif dengan kecemasan matematika. Penelitian ini bertujuan untuk mendeskripsikan profil kreativitas siswa dalam menyelesaikan soal ditinjau dari kecemasan matematika. Jenis penelitian ini adalah penelitian deskriptif kualitatif. Teknik pengumpulan data dalam penelitiam ini menggunakan angket dan tes. Instrumen utama dalam penelitian ini yaitu peneliti sendiri, sedangkan instrumen pendukung yang digunakan yaitu angket kecemasan matematika dan tes penyelesaian soal pola bilangan. Analisis data dalam penelitian ini dilakukan dengan reduksi data hasil angket dan tes, penyajian data, dan penarikan kesimpulan. Materi yang digunakan untuk tes adalah pola bilangan. Pemilihan subjek menggunakan purposive sampling dengan variansi maksimal. Subjek penelitian yang dipilih sebanyak dua siswa, yang terdiri dari satu siswa dari setiap tingkat kecemasan matematika dengan kriteria memiliki Tingkat Kemampuan Berpikir Kreatif (TKBK) tertinggi. Hasil penelitian menunjukkan bahwa siswa yang mengalami kecemasan matematika tinggi hanya dapat menunjukkan komponen kefasihan, sedangkan siswa yang mengalami kecemasan matematika rendah mampu menunjukkan semua komponen kreativitas yaitu kefasihan, kebaruan, dan fleksibilitas. Oleh karena itu, penting bagi guru untuk merancang pembelajaran matematika yang dapat mengurangi kecemasan matematika dan meningkatkan kreativitas siswa dalam menyelesaikan soal.
\end{abstract}

Kata Kunci: berpikir kreatif, kreativitas, kecemasan matematika.

\section{Abstract}

Creativity is a product of creative thinking. Creative thinking is a mental activity that connects one ide to another idea to find various solutions or new ideas in solving problems. One of the factors that can influence students' creative thinking is mathematics anxiety. Mathematics anxiety is a condition experienced by students in the form of feelings of fear and anxiety when faced with mathematical problems. There is a high negative correlation between creative thinking and mathematics anxiety. This research aims to describe the profile of students' creativity in solving problems based on mathematics anxiety. This type of research is a qualitative descriptive study. Data is collected through questionnaires and tests. The main instrument in this study is the researcher, while the supporting instruments used are mathematics anxiety questionnaires and number patterns problems solving tests. Data analysis consisted of reducing questionnaire and test result data, data display, and conclusion drawing. The topic used for the test is a number pattern. The subject selected by purposive sampling with maximum variance. The subjects were two students, consisting of one student from each level of mathematics anxiety with the criteria of having the highest creative thinking ability levels (TKBK). The results showed that students who experienced high mathematics anxiety could only show the components of fluency, while students with low mathematics anxiety can show the all components of creativity consisted of fluency, novelty, and flexibility. Therefore, the teacher needs to design mathematics learning that can reduce mathematics anxiety and increase students' creativity in solving problems. 
Keywords: creative thinking, creativity, mathematics anxiety.

\section{PENDAHULUAN}

Perkembangan Ilmu Pengetahuan dan Teknologi (IPTEK) yang berkembang dengan pesat menuntut manusia untuk selalu berpikir dan menemukan hal-hal baru. Oleh karena itu, pendidikan sangatlah penting bagi kehidupan manusia. Melalui pendidikan, manusia diharapkan mampu mengembangkan kemampuan berpikirnya, salah satunya kemampuan berpikir kreatif. Kemampuan berpikir kreatif harus dimiliki oleh setiap manusia bukan hanya untuk menghadapi persoalan matematika, tetapi juga untuk menyelesaikan masalah yang dialami dalam kehidupan sehari-hari. Pengembangan berpikir kreatif mendapat dukungan yang besar dalam bidang pendidikan. Permendikbud Nomor 20 Tahun 2016 pada Dimensi Keterampilan menegaskan bahwa setiap siswa harus memiliki keterampilan bertindak dan berpikir kreatif. Pernyataan tersebut menunjukkan bahwa berpikir kreatif menjadi unsur penting yang harus diperhatikan dalam pelaksanaan proses pembelajaran.

Panjaitan \& Surya (2017) mengemukakan bahwa berpikir kreatif adalah kemampuan seseorang untuk menciptakan sesuatu yang berbeda dengan yang sudah ada sebelumnya. Berpikir kreatif dapat diartikan sebagai kegiatan mental dilakukan seseorang untuk membangun ide baru (Siswono, 2018:26). Berpikir kreatif sebagai kegiatan mental berkaitan dengan kepekaan terhadap masalah, informasi dan ide-ide baru sehingga dapat dikaitkan untuk digunakan dalam menyelesaikan masalah. "baru" dalam penelitian ini bukan berarti sebelumnya tidak ada, tetapi dapat diartikan sebagai sesuatu yang belum diketahui sebelumnya atau kombinasi dari yang sudah diketahui sebelumnya dan memenuhi kriteria tujuan tertentu.

Matematika merupakan salah satu mata pelajaran yang selalu diajarkan pada setiap jenjang pendidikan. Ini menunjukkan bahwa matematika memiliki peranan yang sangat penting dalam bidang pendidikan. Pentingnya peranan matematika juga dapat dilihat dari manfaat dan kegunaan dalam kehidupan sehari-hari. Matematika bukan hanya mengajarkan berhitung, tetapi juga melatih siswa untuk berpikir kreatif. Davis (dalam Siswono, 2018:4) menjelaskan alasan kreativitas perlu ditekankan dalam pembelajaran matematika karena kehidupan sehari-hari memerlukan matematika, masalah yang ada dalam kehidupan sehari-hari bukan masalah rutin sehingga memerlukan kreativitas dalam menyelesaikannya.

Menurut Siswono (2018), kreativitas dapat dipandang sebagai suatu proses, produk, pribadi/individu, dan situasi/konteks. Untuk memfokuskan penelitian, maka dalam penelitian ini kreativitas diartikan mengacu pada pandangan kreativitas sebagai produk. Hurlock (dalam Siswono, 2018:18) menjelaskan bahwa kreativitas menekankan pada pembuatan produk atau gagasan yang baru dan berbeda yang sebelumya tidak diketahui oleh pembuatnya. Kreativitas merupakan hasil dari kemampuan berpikir kreatif. Hal itu sejalan dengan pendapat Siswono (2018:24) yang menyatakan bahwa kreativitas adalah produk dari kemampuan berpikir kreatif untuk menemukan sesuatu yang baru ketika menghadapi masalah yang harus diselesaikan. Kreativitas diperlukan dalam matematika pada langkah perumusan, penafsiran, menyusun model penyelesaian dan merencanakan penyelesaian. Pada dasarnya kreativitas adalah kemampuan berpikir kreatif untuk menemukan ide-ide baru atau cara yang berbeda.

Terdapat tiga komponen untuk menilai kreativitas, yaitu kebaruan, kefasihan, dan fleksibilitas (Siswono, 2008). Lebih lanjut, Siswono menjelaskan bahwa kebaruan adalah kemampuan siswa untuk dapat memberikan dua atau lebih jawaban yang benar dan berbeda. Kefasihan adalah kemampuan siswa untuk memberikan dua atau lebih jawaban yang beragam dan benar. Fleksibilitas adalah kemampuan siswa untuk dapat memberikan cara yang berbeda dalam menyelesaikan soal. Dua atau lebih jawaban dikatakan beragam jika jawaban tersebut berlainan dan mengikuti pola tertentu, sedangkan dua jawaban disebut berbeda jika jawaban itu berlainan dan tidak mengikuti pola tertentu.

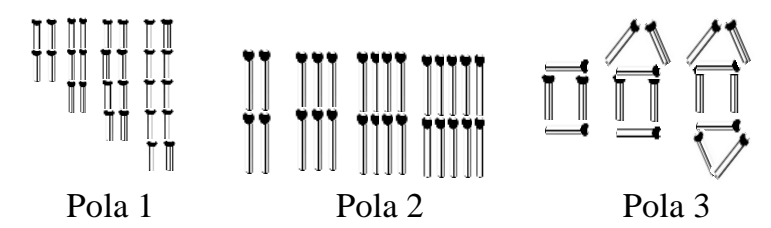

Gambar 1. Contoh jawaban beragam dan benar

Pola 1 dan pola 2 merupakan dua jawaban yang beragam, karena tampak mengikuti pola tertentu. Dua jawaban disebut berbeda jika jawaban tersebut tidak mengikuti pola tertentu, seperti pola 1 dengan pola 3 atau pola 2 dengan pola 3.

Kreativitas siswa menjadi salah satu fokus yang harus dikembangkan dalam pembelajaran matematika. Namun kenyataannya, penelitian yang dilakukan oleh Fardah (2012); Kadir \& La Masi (2014) menunjukkan bahwa kreativitas siswa SMP masih rendah. Hasanah \& Surya (2017:287) menjelaskan penyebab kreativitas siswa tidak berkembang karena kurikulum dirancang dengan target materi yang luas, sehingga guru lebih fokus untuk menyelesaikan materi daripada memberikan metode pembelajaran yang dapat meningkatkan kreativitas siswa. Pembelajaran matematika yang monoton (secara hafalan) meyebabkan siswa tidak dapat mengoptimalkan daya 
imajinasi dan kreativitas yang dimilikinya. Siswa hanya berfokus pada solusi yang diberikan oleh guru, akibatnya siswa tidak mencoba untuk menemukan kemungkinan solusi lain sesuai dengan kreativitas yang mereka miliki.

Faktor internal yang terdapat pada diri siswa juga dapat menyebabkan kreativitas tidak berkembang. Faktor tersebut seperti minat terhadap matematika, kecerdasan, ketekunan, motivasi, dan kondisi fisik siswa. Berdasarkan observasi yang dilakukan oleh peneliti selama Pengenalan Lapangan Persekolahan (PLP), peneliti mendapatkan informasi bahwa siswa menganggap matematika itu sulit, siswa tidak percaya diri akan jawaban yang telah siswa berikan, siswa memiliki rasa takut kepada guru matematika, siswa malu bertanya kepada guru jika ada materi yang belum dipahami, serta siswa mengalami kesulitan dalam memahami simbol matematika. Informasi tersebut menunjukkan bahwa siswa mengalami kecemasan matematika. Mahmood \& Khatoon (2011:170) menyebutkan ciri-ciri siswa yang mengalami kecemasan matematika sebagai berikut: siswa sulit diperintah untuk mengerjakan matematika, tidak dapat mengerjakan tes matematika, dan mengalami sakit secara fisik, pusing, panik, dan takut.

Reali et al (2016) menjelaskan bahwa kecemasan matematika adalah suatu keadaan tidak nyaman yang dialami siswa ketika dihadapkan pada tugas matematika. Klados et al (2017) juga menyebutkan jika kecemasan matematika dapat ditandai dengan keadaan gelisah dalam situasi yang berkaitan dengan matematika. Siswa yang mengalami kecemasan matematika cenderung untuk menghindari situasi dimana mereka harus bertemu, mempelajari, dan mengerjakan matematika. Dengan demikian kecemasan matematika yang dialami oleh siswa dapat mengganggu mereka dalam menyelesaikan soal matematika. Tabrizi et al (2011) menyimpulkan bahwa terdapat korelasi negatif tinggi antara kemampuan berpikir kreatif dan kecemasan matematika. Ini artinya semakin tinggi Tingkat Kemampuan Berpikir Kreatif (TKBK) siswa maka semakin rendah tingkat kecemasan matematika yang dialami siswa.

Berikut penelitian yang berkaitan dengan kreativitas siswa dan kecemasan matematika, yaitu penelitian yang dilakukan oleh Apriliani et al (2016) dengan judul "Analyze of Mathematical Creative Thinking Ability Based on Math Anxiety in Creative Problem Solving Model With SCAMPER Technique", hasil penelitiannya adalah siswa dengan kecemasan matematika tinggi cenderung tidak kreatif, sedangkan siswa yang mengalami kecemasan matematika rendah sangat kreatif. Pratiwi dkk (2019) dalam penelitiannya yang berjudul "Analisis Kemampuan Berpikir Kreatif Matematis pada Pembelajaran Read, Think, Talk, Write Ditinjau dari Kecemasan Matematika" menunjukkan bahwa siswa yang mengalami kecemasan matematika hanya memenuhi komponen fleksbilitas, sedangkan siswa dengan kecemasan matematika rendah mampu memenuhi kefasihan, kebaruan, dan fleksibilitas. Perbedaan dengan penelitian sekarang adalah penelitian ini tidak berfokus pada model pembelajaran yang digunakan, akan tetapi berfokus pada kreativitas siswa dalam menyelesaikan soal.

Berdasarkan uraian di atas, penulisan artikel ini bertujuan untuk mendeskripsikan profil kreativitas siswa dalam menyelesaikan soal ditinjau dari kecemasan matematika.

\section{METODE}

Penelitian ini menggunakan pendekatan penelitian kualitatif dengan jenis penelitian deskriptif. Penelitian kualitatif bertujuan untuk menggambarkan suatu fenomena yang terjadi secara menyeluruh (Siswono, 2019:48). Penelitian ini akan mendeskripsikan profil kreativitas siswa dengan kecemasan matematika tinggi dan rendah dalam menyelesaikan soal. Sumber data penelitian yaitu 27 siswa Kelas VIII-B SMPN 29 Gresik. Pemilihan subjek menggunakan purposive sampling dengan variansi maksimal karena peneliti ingin mendapatkan informasi sehingga harus memilih subjek yang paling banyak dapat dipelajari (Siswono, 2019:176). Subjek penelitian yang dipilih sebanyak dua siswa. Kriteria yang diinginkan yaitu memilih satu siswa dengan Tingkat Kemampuan Berpikir Kreatif (TKBK) tertinggi pada masing-masing tingkat kecemasan matematika.

Untuk pengumpulan data, instrumen utama dalam penelitian ini yaitu peneliti sendiri sedangkan instumen pendukung menggunakan dua jenis teknik pengumpulan data, yaitu angket dan tes. Angket yang digunakan berupa angket kecemasan matematika yang diadaptasi dari Mathematics Anxiety Scale (MAS) yang dikembangkan oleh Mahmood \& Khatoon (2011). Tes berupa tes penyelesaian soal materi pola bilangan. Penelitian dilakukan dengan memberikan angket kecemasan matematika dilanjutkan dengan pemberian tes penyelesaian soal materi pola bilangan untuk mengetahui profil kreativitas siswa. Berikut merupakan instrumen tes penyelesaian soal materi pola bilangan.

1. Roger memiliki batang korek api. Batang korek api tersebut disusun dengan berbagai macam pola.

a) Susunlah batang korek api yang dimiliki Roger menjadi beberapa pola! (minimal dua pola dan susunlah sampai pada gambar ke-5).

b) Tentukan banyak korek api pada gambar ke-n untuk pola-pola yang telah kamu buat pada soal (a) dengan menggunakan 2 cara yang berbeda!

Analisis data dilakukan dengan reduksi data, penyajian data, dan penarikan kesimpulan. Data hasil angket 
kecemasan matematika dianalisis dengan menjumlahkan skor angket masing-masing siswa. Skor yang didapat digunakan untuk menggolongkan siswa ke dalam dua tingkatan kecemasan matematika, dengan ketentuan sebagai berikut.

Tabel 1. Kategori Tingkat Kecemasan Matematika

\begin{tabular}{|c|l|}
\hline Skor & Tingkat Kecemasan Matematika \\
\hline $14-41$ & Rendah \\
\hline $42-70$ & Tinggi \\
\hline
\end{tabular}

Berikut tabel indikator berpikir kreatif yang digunakan untuk menganalisis hasil tes penyelesaian soal.

Tabel 2. Indikator Berpikir Kreatif dalam Menyelesaikan Soal

\begin{tabular}{|l|l|}
\hline \multicolumn{1}{|c|}{$\begin{array}{c}\text { Komponen } \\
\text { Kreativitas }\end{array}$} & \multicolumn{1}{|c|}{ Indikator } \\
\hline Kefasihan & $\begin{array}{l}\text { Memberikan minimal dua } \\
\text { jawaban yang beragam dan } \\
\text { benar dalam menyelesaikan } \\
\text { soal pola bilangan. }\end{array}$ \\
\hline Fleksibilitas & $\begin{array}{l}\text { Menunjukkan penyelesaian } \\
\text { soal pola bilangan dengan } \\
\text { minimal menggunakan dua } \\
\text { cara yang berbeda. }\end{array}$ \\
\hline Kebaruan & $\begin{array}{l}\text { Memberikan minimal dua } \\
\text { jawaban yang berbeda dan } \\
\text { benar dalam menyelesaikan } \\
\text { soal pola bilangan. }\end{array}$ \\
\hline
\end{tabular}

Selanjutnya, dilakukan pengelompokkan berdasarkan Tingkat Kemampuan Berpikir Kreatif yang dikembangkan oleh Siswono (2008:60).

\section{HASIL DAN PEMBAHASAN}

Berdasarkan hasil angket kecemasan matematika dan tes penyelesaian soal, diperoleh dua siswa yang terdiri dari satu siswa dengan TKBK 1 pada kategori kecemasan matematika tinggi dan satu siswa dengan TKBK 4 pada kategori kecemasan matematika rendah. Dengan demikian, dua siswa tersebut yaitu JAK dan PRA dijadikan subjek penelitian. JAK merupakan siswa dengan kecemasan matematika tinggi dan PRA merupakan siswa dengan kecemasan matematika rendah.

\section{Profil Kreativitas Subjek JAK}

Berikut hasil tes penyelesaian soal subjek JAK.

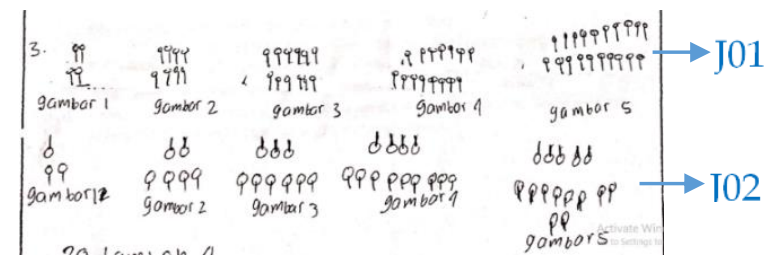

Gambar 2. Hasil Pengerjaan Tes Penyelesaian Soal 1a oleh JAK
Pada gambar di atas menunjukkan bahwa JAK berhasil memberikan dua jawaban yang beragam dan benar (J01 dan J02) dalam menyelesaikan soal pola bilangan. JAK berhasil memenuhi komponen kefasihan karena bisa memberikan minimal dua jawaban yang beragam dan benar. Dua jawaban yang diberikan oleh JAK merupakan dua jawaban yang beragam karena mengikuti pola tertentu. JAK tidak bisa menunjukkan dua jawaban yang berbeda dan benar dalam menyelesaikan soal pola bilangan, sehingga JAK tidak berhasil memenuhi indikator kebaruan.

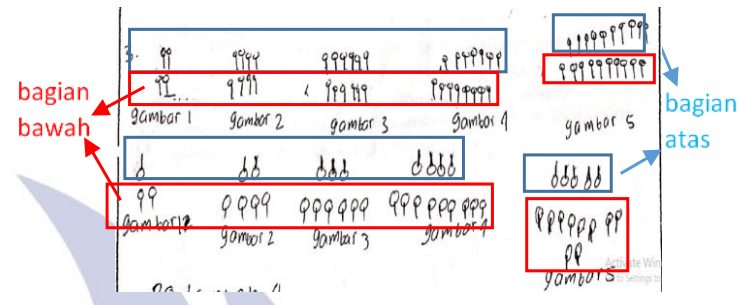

Gambar 3. Penjelasan Jawaban J01 dan J02

Berdasarkan gambar 3, banyak korek api yang dibuat oleh JAK bagian atas J01 dan J02 pada setiap gambar berselisih satu. Pada bagian bawah, banyak korek api yang dibuat pada setiap gambar memiliki jumlah yang sama. Dari penjelasan tersebut maka dapat dikatakan bahwa J01 dan J02 merupakan jawaban yang beragama karena mengikuti pola tertentu.

$$
\text { polake } \begin{array}{rl}
1 & =1 \times 4=4 \\
2 & 2 \times 4=8 \\
3 & 3 \times 4=12 \\
1 & =4 \times 4=16 \\
5 & =5 \times 4=501 \\
N & =\mathrm{N} \times 1=4 \mathrm{~V}
\end{array}
$$

Gambar 4. Hasil Pengerjaan Tes Penyelesaian Soal 1b oleh JAK

JAK hanya bisa menunjukkan penyelesaian soal $1 \mathrm{~b}$ dengan menggunakan satu cara saja. Dengan demikian, JAK tidak mampu memenuhi indikator fleksibilitas dikarenakan tidak bisa menunjukkan penyelesaian soal pola bilangan dengan minimal menggunakan dua cara yang berbeda.

\section{Profil Kreativitas Subjek PRA}

Berikut hasil tes penyelesaian soal subjek PRA.

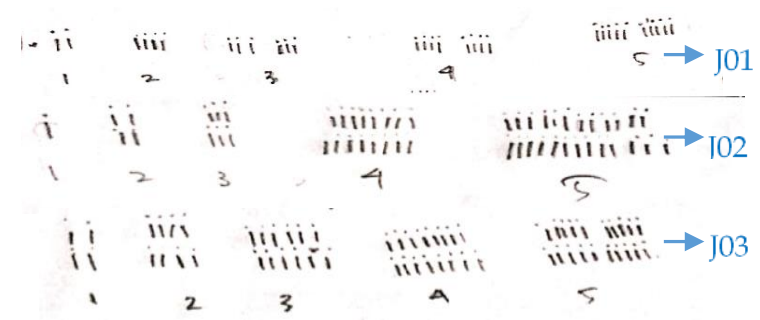


Gambar 5. Hasil Pengerjaan Tes Penyelesaian Soal 1a oleh PRA

PRA berhasil menunjukkan tiga jawaban yang beragam dan benar dalam menyelesaikan soal pola bilangan (J01, J02, dan J03). Dengan demikian, PRA memenuhi indikator kefasihan dikarenakan PRA mampu menunjukkan minimal dua jawaban yang beragam dalam menyelesaikan soal pola bilangan dengan benar. Tiga jawaban yang diberikan oleh PRA (J01, J02, dan J03) merupakan jawaban yang beragam karena korek api disusun mengikuti pola tertentu. Dari ketiga jawaban tersebut, korek api disusun dengan berbaris sehingga ketiganya nampak bahwa mengikuti pola berbaris. Perbedaannya terletak pada banyaknyak korek api pada setiap gambar.

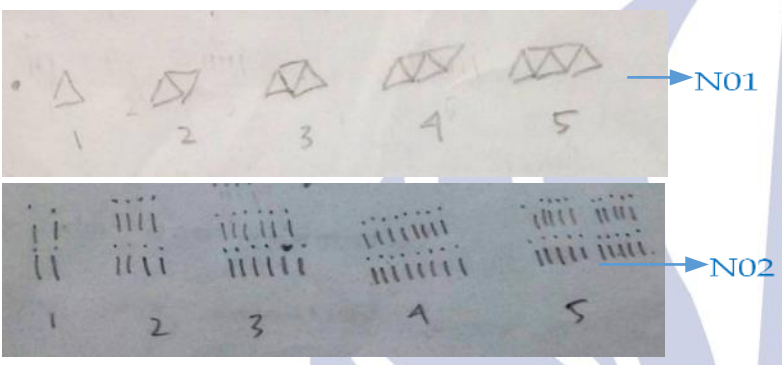

Gambar 6. Kebaruan PRA dalam Menyelesaikan Soal Pola Bilangan

Gambar di atas menunjukkan bahwa PRA berhasil memberikan dua jawaban yang berbeda dalam menyelesaikan soal pola bilangan (N01 dan N02). PRA memenuhi indikator kebaruan karena dapat menunjukkan minimal dua jawaban yang berbeda dan benar dalam menyelesaikan soal pola bilangan. N01 dan N02 dikatakan dua jawaban yang berbeda karena korek api yang disusun tidak mengikuti pola tertentu. Dapat dilihat bahwa pada N01 korek api disusun sehingga membentuk segitiga sedangkan N02 disusun secara berbaris dengan dua baris.

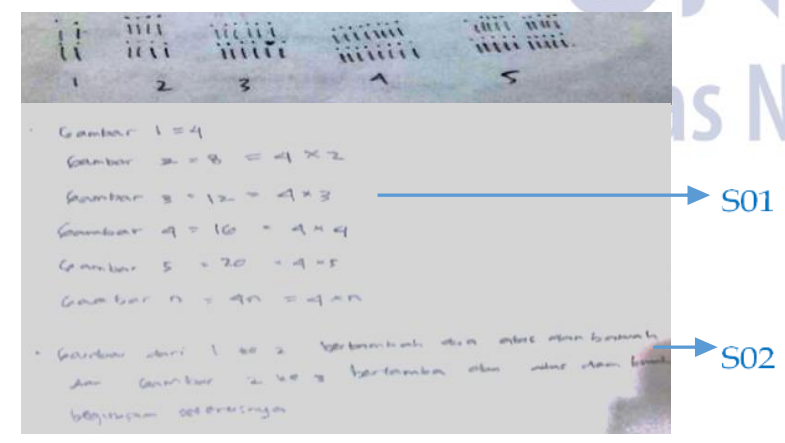

Gambar 7. Hasil Pengerjaan Tes Penyelesaian Soal 1b oleh PRA

Dalam menyelesaikan tes penyelesaian soal $1 \mathrm{~b}$, PRA dapat memberikan dua penyelesaian dengan cara yang berbeda dan benar. PRA mampu menunjukkan penyelesaian soal pola bilangan dengan minimal menggunakan dua cara berbeda, sehingga PRA memenuhi indikator fleksibilitas. PRA menggunakan dua sudut pandang yang berbeda dalam menyelesaikan soal $1 \mathrm{~b}$. Pada S01, PRA memandang banyak korek api pada setiap gambar secara keseluruhan. Kemudian mendata banyak korek api pada setiap gambar. Dari data yang diperolehnya, PRA berhasil menjawab banyak korek api pada gambar ke$\mathrm{n}$ dari pola yang telah dibuatnya dengan benar. Penyelesaian yang ditunjukkan pada S02, PRA memandang pola yang telah dibuatnya menjadi dua bagian, yaitu bagian atas dan bawah. Banyak korek api pada bagian atas dan bawah selalu bertambah dua dari gambar satu ke gambar selanjutnya.

\section{Pembahasan}

Subjek yang mengalami kecemasan matematika tinggi dan rendah memiliki kreativitas yang berbeda. Perbedaan tingkat kecemasan matematika yang dialami subjek memengaruhi kreativitas subjek. Penelitian yang dilakukan oleh Tabrizi et al (2011) menunjukkan adanya korelasi negatif tinggi antara kemampuan berpikir kreatif dengan kecemasan matematika yang dialami oleh siswa. Semakin tinggi tingkat kemampuan berpikir kreatif siswa maka semakin rendah tingkat kecemasan matematika yang dialami siswa. Subjek JAK yang mengalami kecemasan matematika tinggi hanya dapat memenuhi komponen kefasihan, sedangkan subjek PRA yang mengalami kecemasan matematika rendah mampu memenuhi semua komponen kreativitas yaitu kefasihan, kebaruan, dan fleksibilitas. Berdasarkan hasil tersebut dan perjenjangan kemampuan berpikir kreatif yang dikembangkan oleh Siswono (2008) maka subjek dengan kecemasan matematika tinggi berada pada TKBK 1 (kurang kreatif) dan untuk subjek dengan kecemasan matematika rendah berada pada TKBK 4 (sangat kreatif). Penelitian yang dilakukan dengan oleh Pratiwi dkk (2019); Apriliani et al (2016); dan Machromah dkk (2015) menunjukkan hasil yang serupa. Hasil penelitian tersebut menyimpulkan bahwa (1) siswa yang mengalami kecemasan matematika tinggi memiliki TKBK 1 dan (2) siswa yang mengalami kecemasan matematika rendah memiliki TKBK 4.

Richardson \& Suinn (1972:551) menjelaskan bahwa perasaan tegang dan cemas dapat mengganggu perhitungan angka dan penyelesaian soal matematika dalam kehidupan sehari-hari maupun bidang akademik. Kecemasan matematika yang dialami siswa tidak selalu berdampak buruk bagi siswa. Dzulfikar (2013:47) mengungkapkan bahwa kecemasan dapat dianggap sebagai motivasi jika dalam intensitas yang wajar, akan tetapi akan berdampak buruk seperti mengganggu keadaan psikis maupun fisik jika intensitasnya berlebih. Kecemasan matematika tinggi yang dialami siswa dapat menyebabkan pikiran kosong, 
hilang kendali, dan kebingungan ketika menyelesaikan soal matematika (Cavanagh \& Sparrow, 2010). Akibatnya siswa dengan kecemasan matematika tinggi tidak produktif dalam memunculkan ide. Dalam penelitian ini ditunjukkan oleh subjek JAK yang hanya dapat memenuhi komponen kefasihan, sedangkan subjek PRA mampu memenuhi semua komponen kreativitas. Vulpe \& Dafinoiu (2011:1935) menyatakan bahwa siswa dengan kecemasan matematika rendah akan memberikan hasil yang lebih baik pada komponen kreativitas yaitu kefasihan, kebaruan, dan fleksibilitas daripada siswa dengan kecemasan matematika tinggi. Sejalan dengan pendapat tersebut, Apriliani et al (2016) juga menyatakan jika siswa yang mengalami kecemasan matematika rendah produktif dalam memunculkan ide untuk menyelesaikan soal matematika. Tabel 3 di bawah ini menunjukkan simpulan dari hasil penyelesaian subjek penelitian yang telah dianalis sesuai dengan indikator berpikir kreatif ditinjau dari tingkat kecemasan matematika.

Tabel 3. Kreativitas Siswa Ditinjau dari Kecemasan Matematika

\begin{tabular}{|l|c|c|}
\hline \multirow{2}{*}{$\begin{array}{c}\text { Komponen } \\
\text { Kreativitas }\end{array}$} & \multicolumn{2}{|c|}{ Tingkat Kecemasan Matematika } \\
\cline { 2 - 3 } & Tinggi & Rendah \\
\hline Kefasihan & $\checkmark$ & $\checkmark$ \\
\hline Fleksibilitas & - & $\checkmark$ \\
\hline Kebaruan & - & $\checkmark$ \\
\hline
\end{tabular}

Catatan:

$\checkmark \quad$ : mampu memenuhi indikator

- $\quad$ : tidak mampu memenuhi indikator

\section{PENUTUP}

\section{Simpulan}

Berdasarkan uraian di atas, siswa dengan kecemasan matematika tinggi dapat memberikan dua pola yang beragam dalam menyusun korek api, sehingga memenuhi komponen kefasihan. Siswa yang mengalami kecemasan matematika rendah dapat memberikan tiga pola yang beragam dan dua pola yang berbeda dalam menyusun korek api, serta dapat menunjukkan dua sudut pandang yang berbeda dalam mencari banyak korek api pada gambar ke-n. Dengan demikian, siswa yang mengalami kecemasan matematika rendah mampu memenuhi kefasihan, kebaruan, dan fleksibilitas.

\section{Saran}

1. Hasil penelitian menunjukkan bahwa siswa dengan kecemasan matematika tinggi kurang kreatif (TKBK 1) dalam menyelesaikan soal, sehingga guru harus memberi perhatian dan motivasi yang lebih kepada siswa dengan kecemasan matematika tinggi. Misalnya dengan memberi latihan soal yang dianggap mudah terlebih dahulu.
2. Kepada peneliti lain yang akan menindaklanjuti penelitian ini disarankan untuk mengembangkan model pembelajaran yang dapat mengurangi kecemasan matematika yang dialami oleh siswa.

\section{DAFTAR PUSTAKA}

Apriliani, L. R., H. Suyitno, \& Rochmad. 2016. Analyze of Mathematical Creative Thinking Ability Based on Math Anxiety in Creative Problem Solving Model with SCAMPER Technique. International Conference on Mathematics, Science, and Education (ICMSE), 3 (1).

Cavanagh, R., \& Sparrow, L. L. 2010. Measuring Mathematics Anxiety: Paper 1 - Developing a Construct Model. In AARE Conference 2010 Make a Difference, Nov 28, Melbourne: Australian Association for Research in Education Inc.

Dzulfikar, A. 2013. Studi Literatur: Pembelajaran Kooperatif dalam Mengatasi Kecemasan Matematika dan Mengembangan Self Efficacy Matematis Siswa. Prosiding Seminar Nasional Matematika dan Pendidikan Matematika. 9 November 2013. Yogyakarta: Universitas Negeri Yogyakarta. Hal 4554.

Fardah, D. K. 2012. Analisis Proses dan Kemampuan Berpikir Kreatif Siswa dalam Matematika Melalui Tugas Open-Ended. Jurnal Kreano, Jurnal Matematika Kreatif-Inovatif, 3 (2), 91-99.

Hasanah, M. A., \& Surya, E. 2017. Differences in the Abilities of Creative Thinking and Problem Solving of Students in Mathematics by Using Cooperative Learning and Learning of Problem Solving. International Journal of Sciences: Basic and Applied Research (IJSBAR), 34 (01), 286-299.

Kadir \& La Masi. 2014. Mathematical Creative Thinking Skills Of Students Junior High School In Kendari City. Makalah ini disajikan dalam International Seminar on Innovation in Mathematics and Mathematics Education 1st ISIM-MED 2014 "Innovation and Technology for Mathematics and Mathematics Education" Department of Mathematics Education, Yogyakarta: State University Yogyakarta, 295-306.

Klados, M. A., Pandria, N., Micheloyannis, S., Margulies, D., \& Bamidis, P. D. 2017. Math anxiety: Brain cortical network changes in anticipation of doing mathematics. International Journal of Psychophysiology, 122, 24-31.

Machromah, I. U., Riyadi R., \& Usodo B. 2015. Analisis Proses dan Tingkat Berpikir Kreatif Siswa SMP Dalam Pemecahan Masalah Bentuk Soal Cerita Materi 
Lingkaran Ditinjau Dari Kecemasan Matematika. Jurnal Elektronik Pembelajaran Matematika. 3 (6), 613-624.

Mahmood, S., \& Khatoon, T. 2011. Development and Validation of the Mathematics Anxiety Scale for Secondary and Senior Secondary School Students. British Journal of Arts and Social Sciences, 2 (2), 169179.

Panjaitan, A. H., \& Surya, E. 2018. Creative Thinking (Berpikir Kreatif) Dalam Pembelajaran Matematika. Diakses Di Https://Www. Researchgate. Net/Publication/321849189 (Diunduh 10 September 2019).

Permendikbud 2016 No. 20, Standar Kompetensi Lulusan Pendidikan Dasar dan Menengah.

Pratiwi, L. A., Dwijanto, Kristina W. 2019. Analisis Kemampuan Berpikir Kreatif Matematis pada Pembelajaran Read, Think, Talk, Write, Ditinjau dari Kecemasan Matematika. PRISMA, Prosiding Seminar Nasional Matematika. 576-582.

Reali, F., Jiménez-Leal, W., Maldonado-Carreño, C., Devine, A., \& Szuics, D. 2016. Examining the link between math anxiety and math performance in Colombian students. Revista Colombiana de Psicología, 25(2), 369-379.
Richardson, Frank C., \& Suinn, R. M. (1972). The Mathematics Anxiety Rating Scale: Psychometric Data. Journal of Counseling Psychology, 19 (6), 551554.

Siswono, T. Y. E. 2008. Proses Berpikir Kreatif Siswa dalam Memecahkan dan Mengajukan Masalah Matematika. Jurnal Ilmu Pendidikan Universitas Negeri Malang, 15 (1), 60-68.

Siswono, T. Y. E. 2018. Pembelajaran Matematika Berbasis Pengajuan dan Pemecahan Masalah. Bandung: PT. Remaja Rosdakarya.

Siswono, T. Y. E. 2019. Paradigma Penelitian Pendidikan: Pengembangan Teori dan Aplikasi Pendidikan Matematika. Bandung: PT. Remaja Rosdakarya.

Tabrizi, E. A., Talib, M. A., \& Yacoob, S. N. 2011. Relationship Between Creative Thinking And Anxiety Among Adolescent Boys And Girls In Tehran, Iran. International Journal of Humanities and Social Science, 1 (19), 60-66.

Vulpe, A., \& Dafinoiu, I. 2011. Positive Emotions' Influence on Attitude Toward Change, Creative Thinking and Their Relationship With Irrational Thinking in Romanian Adolescents. Procedia-Social and Behavioral Sciences, 30, 1935-1941.

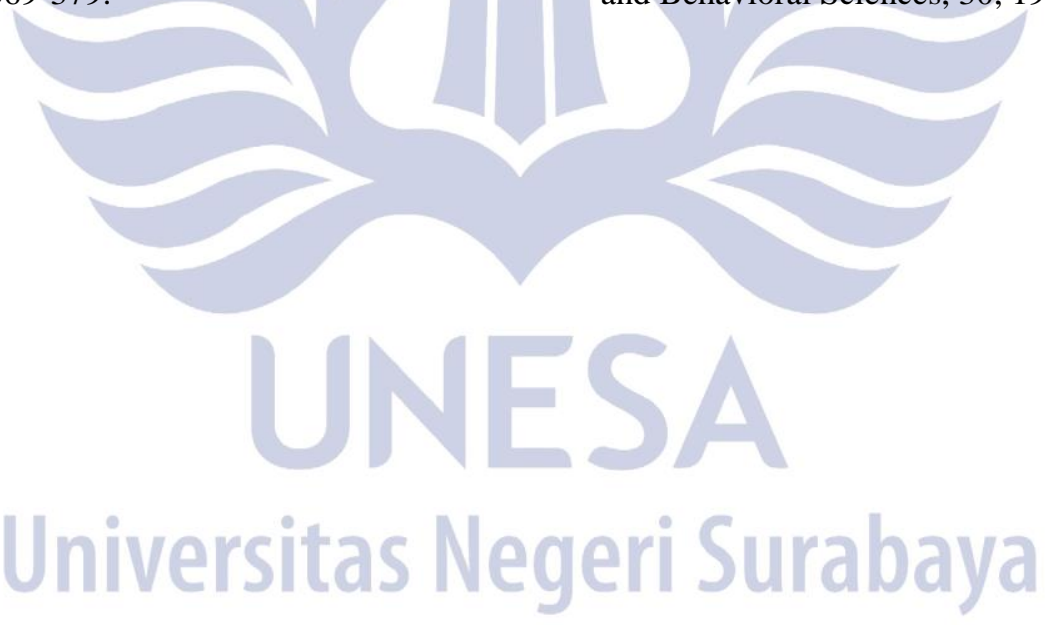

